\title{
Origin of the Chinese word for "cell": an unusual but wonderful idea of a mathematician
}

\author{
He Zhang ${ }^{1,2 \bowtie ~}$ \\ ${ }^{1}$ School of Marxism, Bengbu Medical College, Bengbu 233030, China \\ 2 Department for the History of Science and Scientific Archaeology, University of Science and Technology of China, Hefei \\ 230026, China \\ $\triangle$ Correspondence: zhangheahu@163.com (H. Zhang)
}

Accepted August 24, 2020

In today's biology and even the whole field of natural science, "cell" is undoubtedly a central concept. Even in everyday life, it is a well-known common word. Then, who could have thought that "xibao" (细胞), the Chinese word for "cell", was not coined by a biologist, but was instead the inspired idea of a mathematician! This mathematician is Shanlan Li (李善兰), an exceptional scholar from the late Qing dynasty.

Shanlan Li (Fig. 1) was born on January 2nd, 1811 in Haining, Zhejiang Province. He was obsessed with mathematics since he was a child. When he was 9 years old, he found the Nine Chapters on the Mathematical Art on the shelf. He immediately read this ancient Chinese mathematical masterpiece, and became enamored with mathematics. At the age of 14 , he taught himself the first six volumes of the Chinese version of Euclid's Elements. After the age of $30, \mathrm{Li}$ started in-depth study of mathematics, and began to write books on it. By the age of 40 , he had published several mathematical monographs and become a renowned mathematician. His mathematical research represented the most advanced level of Chinese mathematics at the time. Li was also a pioneer of calculus in China (Wang, 2000).

In the summer of 1852, Li presented his mathematical works to foreign missionaries at the London Missionary Society Press (Mo Hai Shu Kuan) in Shanghai, and was commended by Alexander Wylie and colleagues. From there on, Li cooperated with Alexander Wylie, Joseph Edkins and others to translate western scientific writings, successively publishing a number of important translations. In 1858, the Press published a translation titled Chih-wu hsüeh (Botany) (Fig. 2), which was compiled and translated by Alexander Williamson and Joseph Edkins, two British missionaries, together with Shanlan Li. As the first translated work on modern Western botany, this translation catalyzed the spread of modern Western botany in China. The Chinese word for cell, "xibao" (细胞), originated in this translation.

For a long time, the original foreign source of Chih-wu hsüeh (Williamson et al., 1858) had generally been regarded as a problem. Recently, studies concluded that at least four original sources were compiled into Chih-wu hsüeh, including Lindley's 1847 or 1849 The Elements of Botany, John Hutton Balfour's 1851 Phyto-Theology, Lindley's 1853 The Vegetable Kingdom, and Volume 1 of Chambers' Information for the People published by William and Robert Chambers in 1848 (Zhang, 2018). The edition of Lindley's The Elements of Botany was identified as that from 1849 (Fig. 3) by the author's textual research.

According to the studies of linguists, most free translations of foreign words in modern Chinese were not invented by Chinese people, but borrowed from the original translations of Japanese authors who used Chinese characters (Wang, 2012). Even common everyday words of modern Chinese such as "science", "society", "nation" and "religion" come from the translations of Western languages by Japanese scholars, let alone a large number of academic Chinese words like "atom" and "molecule". However, quite a few words were originally translated by Chinese authors, with "cell" being a notable representative.

Academics mostly agree on the origin of the Chinese word “xibao" (细胞) in Chih-wu hsüeh, the first translated work in Chinese on modern Western botany. The description at the beginning of the second volume of the book (Fig. 4), “此细胞一胞为一体, 相比附而成植物全体” (Each cell is an independent unit, and they are interconnected to constitute a whole plant.), is often considered the paragraph in which "cell" was translated as “细胞" for the first time. At first glance, this statement is not problematic, because this is indeed where the Chinese characters of word "cell" shows 


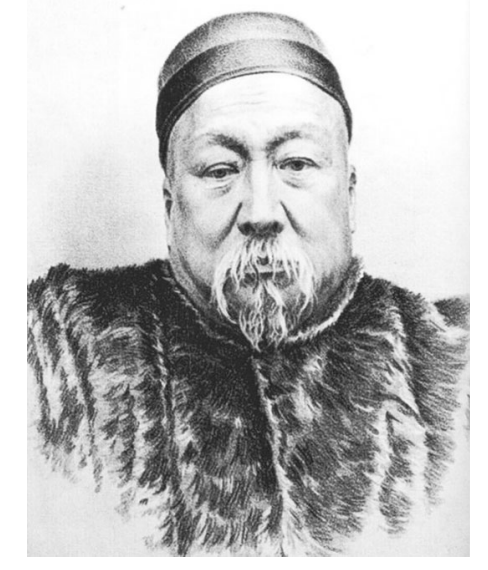

Figure 1. Shanlan Li (1811-1882).

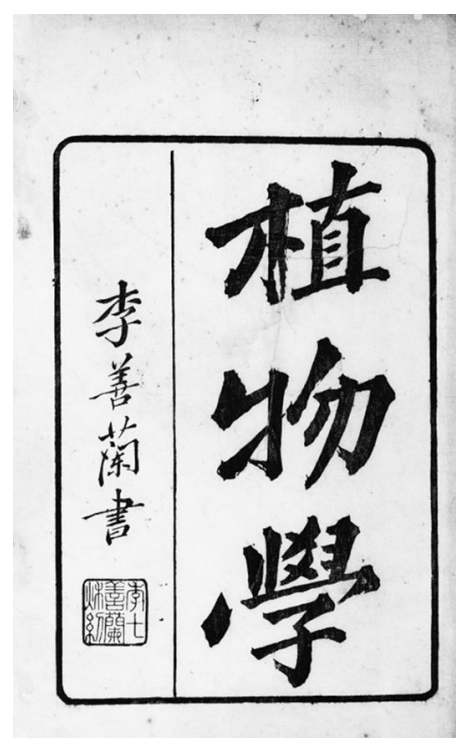

Figure 2. Chih-wu hsüeh, by Alexander Williamson, Joseph Edkins, and Shanlan Li in 1858.

up for the first time in the book Chih-wu hsüeh. However, by referring to the English original, we can find the source text "Each vesicle is a distinct individual, cohering with the vesicle with which it is in contact." is located on page 3 of Lindley's 1849 The Elements of Botany. The Chinese characters of word "cell" here corresponds to the English word "vesicle" instead of "cell". In fact, the sentence “聚胞体乃聚无 数细胞为一体, 诸细胞相粘合” (The aggregation integrates innumerable cells into one. These cells are bonded with each other.) on Page 1b of the second volume (Fig. 5) is the real origin translation of "cell" as Chinese characters, and its source text is not Lindley's 1849 The Elements of Botany, but rather "It consists of a great number of cells of irregular shape, which adhere together." on page 69 of Volume 1 of
THE

\section{ELEMENTS OF BOTANY,}

STRUCTURAL, PHYSIOLOGICAL, \& MEDICAL.

apixo

A SIXTH EDITION OF THE OUTLINE OF THE FIRST PRINCIPLES OF BOTANY.

w1тB

A SKETCH OF THE ARTIFICIAL METHODS OF CLASSIFICATION,

AND

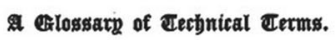

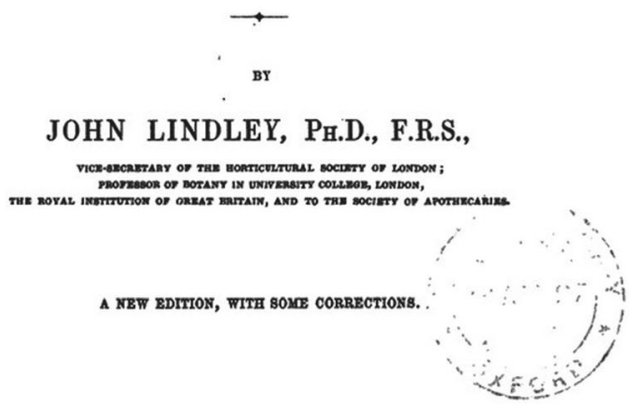

LONDON :

BRADBURY \& EVANS, 11, BOUVERIE STREET,

FLEET STREET.

xDCocxux.

Figure 3. The Elements of Botany, by John Lindley in 1849.

Chambers' Information for the People published in 1848 (Fig. 6).

A popular viewpoint was that Li understood "cell" as "a small body with a membrane", so he should have translated “cell” as “小胞” in Chinese. Since Li was from Haining, Zhejiang Province, and "small" (小) is used interchangeably with "thin" (细) in his dialect, he finally translated "cell" as "细 胞”. This is why the Chinese word “细胞” was not recognized by the public for a long time (Yang, 2006). However, one meaning of "细" was "small or thin" in ancient Chinese (Xu, 2007), which conforms to the meaning of "cell". Thus, it is not unsubstantiated to translate "cell" as “细胞”, and Li was unnecessarily considered to have been mainly influenced by his dialect. The main reason why the Chinese word "cell" was not recognized by the public for a long time is that the book Chih-wu hsüeh was not very popular in Chinese society of the late Qing dynasty and had little influence. However, the book was spread to Japan several years after it was published, and had a great influence on the development of modern botany there. The Chinese word "cell" became a botanical and anatomical term after it was introduced into Japan, and later inspired the word "细菌" 


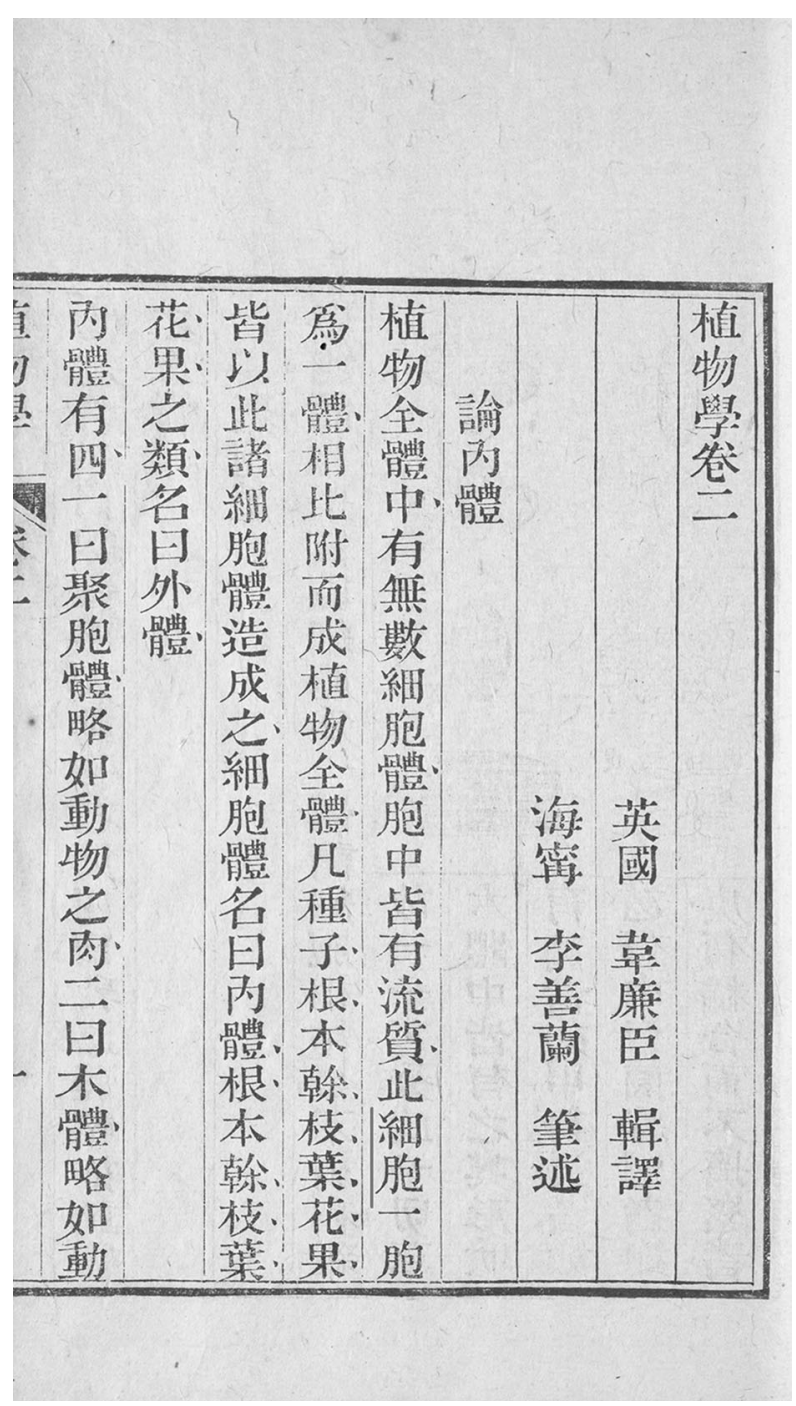

Figure 4. Page 1a of volume 2 of Chih-wu hsüeh.

(bacterium) (Shen, 2010). In the wave of the introduction of Western learning from Japan in the early 20th century, Chinese words such as "cell" were passed back from Japan, which in turn had a profound influence on China.

Throughout the book Chih-wu hsüeh, Chinese translations of “细胞” other than "cell" included "locule", "ovary" and so on. Especially, although "cell" was not necessarily translated into as “细胞”, it can be seen that the translator clearly understood the concept of “细胞”, because he could distinguish the different kinds of concepts. Thus, the conclusion (Huang, 2016) that the translator was pessimistic or hesitant about the translation "cell" based on the lowest frequency of Chinese word “细胞” among the Chinese translations of "cell" was untenable.

It has been more than 160 years since the book Chih-wu $h s u ̈ e h$ was published, and many Chinese terms translated

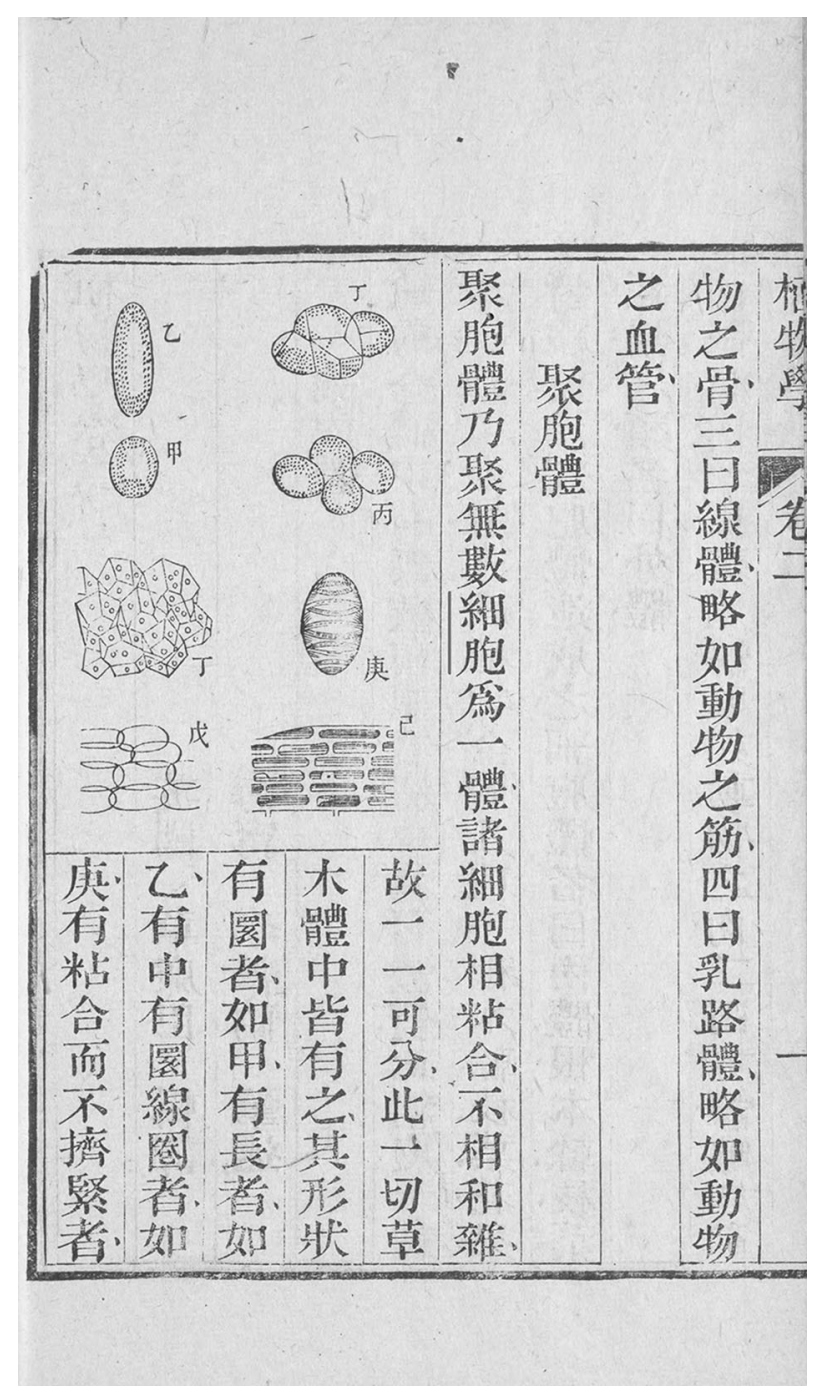

Figure 5. Page 1b of volume 2 of Chih-wu hsüeh.

from English have changed to different extents in the course of development. Even for the Chinese terms that are still in use today, the meaning and scope of the denoted concepts may have changed significantly. The Chinese word “细胞” is no exception. Now, it refers especially to the basic unit of the structure and function of organisms, and has almost completely lost the other meanings given in Chih-wu hsüeh.

Shanlan $\mathrm{Li}$, a well-known mathematician of the late Qing dynasty, participated in the translation and publication of many important scientific textbooks, covering mathematics, mechanics, astronomy, botany and other subjects. He was also the first person to introduce algebra, analytic geometry, calculus, botany and other modern Western sciences into China, promoting the spread of modern science in China. As a well-deserved pioneer of modern Chinese science, $L i$ is worth remembering by people forever. 


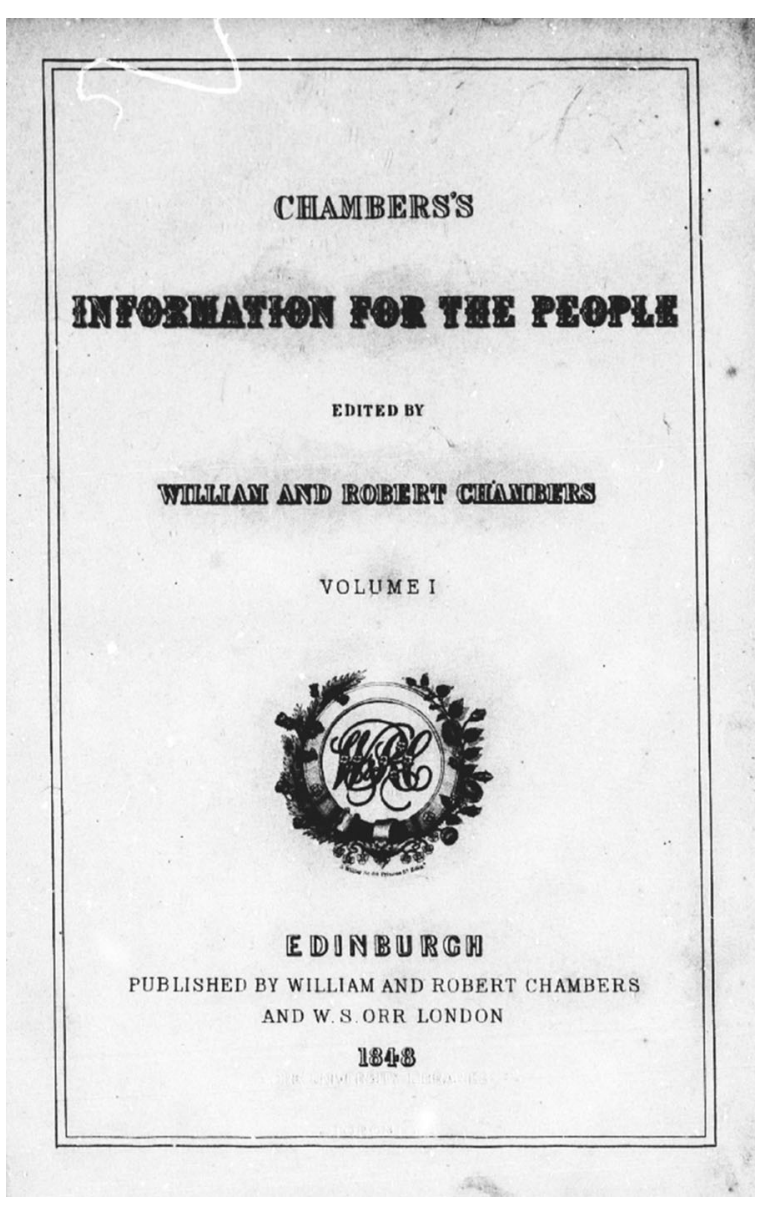

Figure 6. Volume 1 of Chambers' Information for the People, by William and Robert Chambers in 1848.

\section{ACKNOWLEDGEMENTS}

This work was supported by grants from the Demonstrative School of Marxism and Excellent Teaching and Research Team Construction Program of Colleges and Universities of the Ministry of Education of China (Grant No. 19JDSZK151) and Humanity and Social Science Key Research Project of Anhui Educational Committee (SK2018A1073).

\section{OPEN ACCESS}

This article is licensed under a Creative Commons Attribution 4.0 International License, which permits use, sharing, adaptation, distribution and reproduction in any medium or format, as long as you give appropriate credit to the original author(s) and the source, provide a link to the Creative Commons licence, and indicate if changes were made. The images or other third party material in this article are included in the article's Creative Commons licence, unless indicated otherwise in a credit line to the material. If material is not included in the article's Creative Commons licence and your intended use is not permitted by statutory regulation or exceeds the permitted use, you will need to obtain permission directly from the copyright holder. To view a copy of this licence, visit http:// creativecommons.org/licenses/by/4.0/.

\section{REFERENCES}

Balfour JH (1851) Phyto-theology; or, botanical sketches, intended to illustrate the works of god in the structure, functions, and general distribution of plants. Johnstone \& Hunter, London

Chambers W, Chambers R (1848) Chambers' information for the people, vol 1. W. \& R. Chambers, Edinburgh

Huang HQ (2016) Traceability of "xibao". China Terminology 18 (5):56-58 (黄河清. 2016. “细胞”探源. 中国科技术语, 18(5):56-58)

Lindley $\mathrm{J}$ (1847) The elements of botany, structural and physiological; being a fifth edition of the outline of the first principles of botany. Bradbury \& Evans, London

Lindley J (1849) The elements of botany, structural, physiological, and medical. Being a sixth edition of the outline of the first principles of botany. Bradbury \& Evans, London

Lindley J (1853) The vegetable kingdom: or, the structure, classification, and uses of plants, illustrated upon the natural system, 3rd edn. Bradbury \& Evans, London

Shen GW (2010) A study of the lexical exchange between modern China and Japan: coining, acception, and sharing of new words of Chinese characters. Zhonghua Book Company, Beijing (沈国 威. 2010. 近代中日词汇交流研究: 汉字新词的创制、容受与共享. 北京:中华书局)

Wang $L$ (2012) A history of the Chinese lexicon. Zhonghua Book Company, Beijing (王力. 2012. 汉语词汇史. 北京:中华书局)

Wang YS (2000) Shanlan Li: pioneer of modern science in China. Science Press, Beijing (王渝生. 2000. 中国现代科学的先驱: 李善 兰. 北京:科学出版社)

Williamson A, Edkins J, Li S (1858) Chih-wu hsüeh. London Missionary Society Press, Shanghae (韦廉臣, 艾约瑟, 李善兰. 1858. 植物学. 上海:墨海书馆)

Xu F (2007) Ancient Chinese dictionary. Shanghai Lexicographical Publishing House, Shanghai (徐复. 2007. 古代汉语大词典. 上海: 上海辞书出版社)

Yang ZQ (2006) Well-versed in both Chinese and Western knowledge: biography of Shanlan Li. Zhejiang People's Publishing House, Hangzhou (杨自强. 2006. 学贯中西:李善兰传. 杭州:浙江 人民出版社)

Zhang H (2018) The symbol of spread of modern Western botany into China: Chih-wu hsüeh, an unconventional translation in the late Qing dynasty. Protein Cell 9(6):511-515 